\title{
Analisis krisis public relations pada peristiwa tumbangnya pohon di Kebun Raya Bogor
}

\author{
Ayi Doni Darussalam, Dyah Rachmawati Sugiyanto², Djuara Pangihutan Lubis ${ }^{3}$ \\ ${ }^{1,3}$ Institut Pertanian Bogor, Bogor, Indonesia \\ ${ }^{1,2}$ Lembaga Ilmu Pengetahuan Indonesia, Jakarta, Indonesia
}

\begin{abstract}
ABSTRAK
Kejadian tumbangnya Pohon Damar pada Minggu 11 Januari 2015 telah menyebabkan tujuh orang pengunjung di Kebun Raya Bogor meninggal dunia. Adanya berbagai pemberitaan negatif di media massa serta menurunnya kepercayaan stakeholders telah menjadi krisis yang menerpa manajemen Kebun Raya Bogor. Penelitian ini bertujuan mengetahui jenis krisis dan jenis respon krisis dalam konsep Situational Crisis Communication Theory pada kasus tumbangnya pohon di Kebun Raya Bogor. Metode yang digunakan dalam penelitian dengan deskriptif kualitatif, sedangkan pengambilan data dilakukan dengan observasi, wawancara dan studi pustaka terhadap pemberitaan di media massa, website dan media sosial. Berdasarkan hasil penelitian, krisis yang terjadi merupakan jenis Victim Cluster di mana krisis terjadi karena faktor alam. Selain itu, krisis ini juga digolongkan ke dalam jenis Preventable Cluster di mana Kebun Raya Bogor dinilai lalai dalam melakukan pengawasan terhadap koleksi pohon terutama yang perpotensi rawan tumbang. Sedangkan strategi respon krisis yang dilakukan dengan Rebuild Crisis Response Strategies berupa pemberian kompensasi serta permintaan maaf terhadap keluarga korban. Selain itu, penguatan strategi respons krisis (Bolstering Crisis Response Strategies) juga dilakukan dengan meyakinkan para pemangku kepentingan tentang hubungan yang baik di masa lalu sebelum krisis. Tim komunikasi krisis juga mengatur dalam kerangka menganalisis masalah, menyusun pesan-pesan utama dan menjadi narasumber di media massa. Untuk mengurangi krisis tim hubungan masyarakat LIPI melakukan liputan positif besar-besaran di berbagai saluran media, seperti di media sosial, situs web dan media massa terkait pencapaian dan kegiatan penelitian di Kebun Raya Bogor.
\end{abstract}

Kata-kata Kunci: Krisis; hubungan masyarakat; komunikasi; dampak, analisis

\section{Public relations crisis analysis on collapsing tree incident in Bogor Botanical Gardens} ABSTRACT

The Damar Tree collapsing incident on Sunday, January 11, 2015, killing seven visitors at the Bogor Botanical Gardens. Some various adverse reports published in mass media and the decline in stakeholder trust generate a crisis that has hit the Bogor Botanical Gardens' management. This study aims to determine the type of crisis and crisis response in the Situational Crisis Communication Theory concept for the collapsing tree incident. The method used in this research is descriptive qualitative, using data collection from observation, interviews, and literature study of the news in mass media, websites, and social media. Research results show that the crisis that occurred was a type of Victim Cluster in which the crisis occurred due to natural factors. This crisis is also classified into the Preventable Cluster type in which the Bogor Botanical Gardens are considered negligent in monitoring those trees in the collection, especially those that are potentially prone to collapse. Meanwhile, the crisis response strategy is carried out with the Rebuild Crisis Response Strategies, providing compensation and apologies to victims'families. Bolstering Crisis Response Strategies was also carried out by convincing stakeholders about good relations in the past before the crisis. The crisis communication team also arranged a framework for analyzing problems, compiling main messages as mass media resource. To reduce the crisis, the LIPI public relations team conducted massive positive coverage on various media channels, such as social media, websites, and mass media related to the achievements and research activities at the Bogor Botanical Gardens.

Keywords: Crisis; public relations; communication; impact; analysis

Korespondensi: Ayi Doni Darussalam, S.I.Kom, IPB, Darmaga, Bogor 16680, Indonesia. E-mail: doni. darussalam@gmail.com 


\section{PENDAHULUAN}

Peristiwa tumbangnya sebuah pohon damar atau Agathis dammara pada Minggu 11 Januari 2015 mengakibatkan sebanyak tujuh orang meninggal dunia dan sejumlah pengunjung lainnya mengalami luka-luka baik ringan maupun berat. Saat itu pengunjung dari pegawai PT Assalta Mandiri Agung sedang mengadakan kegiatan gathering di area lapangan sekitar Jalan Astrid. Area tersebut merupakan salah satu zona yang menjadi pusat berkumpulnya pengunjung di dalam kebun raya.

Sebelum kejadian, petugas keamanan yang sedang berjaga di lokasi tersebut memperingatkan kepada para pengunjung untuk meninggalkan lokasi karena terdengar suara patahan pada batang pohon bagian atas. Sebagian pengujung sudah berpindah namun sebagian lain tidak sempat menyelamatkan diri sehingga terkena robohan pohon (Risna, 2015).

Suara patahan batang pohon tersebut dibenarkan oleh Yudi salah seorang korban selamat. Menurutnya saat para pengunjung tersebut sedang berdiskusi di bawah membahas kenaikan upah minimum karyawan, terdengar suara retakan pohon dan langsung tumbang dengan sangat cepat sehingga tidak ada waktu untuk menyelamatkan diri. Banyak pengunjung terjepit dan mengalami luka-luka (Bempah, 2015).
Tumbangnya pohon di Kebun Raya memang tidak terduga. Teknisi perkebunrayaan telah rutin mengecek kondisi pepohonan, tumbuhan, dan tanaman. Tidak ditemukan kondisi pohon yang rusak atau menunjukkan gejala akan tumbang. Saat peristiwa pohon tersebut tumbang, kondisi cuaca cerah dan tidak sedang hujan atau pun angin kencang.

Peristiwa ranting patah dan pohon tumbang merupakan hal biasa di Kebun Raya Bogor. Sebagai makhluk hidup, pohon juga pasti memiliki siklus hidup. Siklus akhir alamiah pohon pada umumnya terjadi karena mengering atau tumbang. Seperti tumbangnya pohonpohon Leci (Lithi chinensis Sonn) yang berusia 194 tahun pada tahun 2017 (Junita, 2017).

Hasil analisis pihak kepolisian dan tim peneliti dari IPB dugaan sementara pohon damar yang tumbang mengalami keroposan di dalam yang diakibatkan oleh rayap, meskipun terlihat sehat nampak diluar. Sumber pihak manajemen kebun raya menyebutkan bahwa Standard Operational Procedure (SOP) perawatan koleksi sudah dilakukan oleh petugas pengawas koleksi dari Subbidang Pemeliharaan Koleksi.

Suatu peristiwa krisis paling banyak terjadi karena tidak diketahui dan tidak diantisipasi (Kriyantono, 2012). Seyogianya, apabila manajemen proaktif dalam menganalisis isu internal, isu eksternal dan situasi lingkungan bisa saja krisis dicegah (Suharyanti \& Sutawidjaya, 
2012). Pencegahan krisis dapat dilakukan melalui pembelian alat deteksi kesehatan pohon sonic tomograph lebih dini sebagai upaya mengantisipasi tumbangnya koleksi tanaman, namun hal tersebut dilakuan setelah kejadian terjadi.

Akibat tumbangnya pohon damar di Kebun Raya Bogor tersebut, telah berdampak pada persepsi negatif masyarakat terhadap manajemen pengelola Kebun Raya Bogor. Hal ini terlihat dari pemberitaan di media massa yang muncul pasca kejadian. Hasil penelusuran tim humas dari subbagian kerjasama dan informasi Kebun Raya Bogor terhadap pemberitaan media online, ada sekitar 45 pemberitaan dari tanggal 11 - 19 Januari 2015.

Subbagian kerjasama dan informasi Kebun Raya Bogor mempunyai peran sentral dalam meredam gejolak krisis, baik dalam kaitannya dengan media massa maupun dengan stakeholders. Pada kesempatan ini juga subbagian kerjasama dan informasi berkolaborasi dengan Biro Kerjasama Hukum dan Humas Lembaga Ilmu Pengetahuan Indonesia (LIPI), sebagai satuan kerja di kantor LIPI pusat yang bertanggung jawab dalam kehumasan.

Menurut Yulianti \& Boer unit kerja atau divisi yang berkaitan dengan kehumasan atau public relations memiliki tanggung jawab dan tugas dalam mengelola komuniskasi terutama dalam penanganan komunikasi krisis di sebuah lembaga (Yulianti \& Boer , 2020). Hal yang bisa dilakukan yaitu dengan meminimalkan dampak negatif terhadap citra dan reputasi lembaga, dengan cara menyiapkan manajamen krisis dari mulai perencanaan sampai dengan evaluasi.

Berdasarkan analisis terhadap isi pemberitaan di media massa, di hari pertama kejadian, isu yang muncul yaitu terkait jumlah korban tewas, pemaparan fakta kronologi kejadian proses tumbangnya pohon, serta penanganan dan evakuasi terhadap korban. Pada hari-hari berikutnya isu yang muncul sudah mengarah pada adanya indikasi tindakan kelalaian yang dilakukan manajemen dalan pengawasan dan perawatan pohon, dan terakhir isu terkait penetapan tersangka oleh pihak kepolisian terhadap tiga orang pegawai Kebun Raya Bogor. Hal ini kemudian menyebabkan krisis terhadap reputasi dan citra lembaga.

Krisis yang terjadi terhadap suatu organisasi bisa menyebabkan banyak hal. Ada tiga hal yang mungkin bisa terjadi terhadap suatu organisasi yang mengalami krisis yaitu Pertama, ditutup atau bergabung dengan organisasi lain bahkan dinyatakan bangkrut. Kedua, keberadaaanya masih ada namun mengalami kerugian keuangan, menurunnya kepercayaan masyarakat, kehilangan market share yang memerlukan jangka waktu yang 
lama untuk mengembalikannya ke keadaan semula. Ketiga, organisasi justru mengalami tingkat kepercayaan yang lebih baik dari kondisi sebelum krisis (Kriyantono, 2019).

Perusahaan harus terus melakukan komunikasi krisis karena tersebut merupakan syarat utama disaat krisis. Hal ini karena ketika kondisi sudah pulih biasanya investor akan mengingatnya untuk membangun kerjasama dan berinvestasi (Suryani \& Sagiyanto, 2018).

Pada kesimpulan penelitiannya tentang manajemen krisis yang dilakukan British Petroleum (BP) saat terjadi krisis akibat tumpahan minyak di Deepwater Horizon Teluk Meksiko tanggal 20 April 2010, De Wolf \& Mohamed mengatakan, pada saat krisis reputasi dan citra positif perusahaan terdampak sangat signifikan. Menariknya, ditemukan juga hubungan yang erat antara kepedulian perusahaan dalam bentuk tanggung jawab sosial perusahaan dengan strategi manajemen krisis perusahaan dalam mengurangi beban krisis (De Wolf \& Mohamed, 2013). Pada akhirnya keberadaan krisis bisa menjadi sebuah pembelajaran yang memberikan potensi kekuatan bagi sebuah organisasi kedepannya.

Secara umum, krisis dapat diterjemahkan sebagai sesuatu yang datang secara tiba-tiba, yang kadangkala tidak terdeteksi atau tidak dapat diprediksi dan dapat menjadi ancaman bagi organisasi. Organisasi dituntut sigap dan cepat dalam menangani suatu ancaman yang diakibatkan dari munculnya krisis sehingga dampak yang ditimbulkan tidak menimbulkan kerugian baik materil maupun imateril (Prastya, 2011).

Sedangkan Coombs mendefinisikan krisis sebagai persepsi terhadap suatu kondisi yang muncul secara tiba-tiba yang dapat memberikan tekanan terhadap stakeholders dengan sangat serius, yang berdampak terhadap kinerja dan berakhir pada kondisi kurang menguntungkan (Coombs, Timothy \& Holladay, 2010). Adapun upaya yang harus dilakukan yaitu dengan melakukan komunikasi krisis yang tepat, dimana proses analisis terhadap isu, proses dan penyebaran informasi diperlukan untuk menangani kondisi krisis.

Tentunya komunikasi krisis baik dengan interaksi verbal, visual maupun tertulis terhadap sstakeholders perlu dilakukan baik sebelum, selama dan setelah kejadian sehingga bisa meredam gejolak dan menjaga kepercayaan masyarakat (Fearn-Banks, 2007).

\section{Situational Crisis Communication Theory} (SCCT) dalam hal ini menyediakan mekanisme bagi para manajer krisis untuk mengantisipasi bagaimana reaksi yang dilakukan oleh stakeholders terhadap ancaman krisis yang dapat memengaruhi reputasi citra organisasi. Selain itu, SCCT meramalkan reaksi stakeholders terhadap strategi respons krisis yang dilakukan 
oleh manajemen krisis dalam untuk mengelola krisis (T. Coombs, 2007).

Lebih jauh Coombs menekankan dalam SCCT, atribusi stakeholders memiliki pengaruh terhadap reputasi organsiasi. Dengan demikian, manajer krisis bisa mengetahui caranya stakeholders dalam merespons krisis (Coombs, 2007). Penelitian empiris dari SCCT menyediakan suatu pedoman bagi para manajer krisis bagaimana strategi respon krisis dapat dipakai untuk melindungi repustasi sebagai akibat krisis yang timbul. Penelitian yang dilakukan oleh Akhyar \& Pratiwi menunjukan bahwa SCCT bisa menjadi kerangka berfikir dalam mengungkap krisis komunikasi yang terjadi di PT Telkomsel dan PT Indosat dengan membahas jenis-jenis krisis dan juga strategi respon krisis (Akhyar \& Pratiwi, 2019).

Penelitian ini bertujuan mengidentifikasi jenis krisis dan jenis respon krisis yang terjadi dalam kasus tumbangnya pohon di Kebun Raya Bogor. Salah satu alasan yang menjadi urgensi penelitian adalah karena Kebun Raya LIPI merupakan pusat penelitian konservasi tumbuhan di Indonesia.

Kebun Raya Bogor sebagai salah satu unit kerja di LIPI lebih terkenal sebagai tempat rekreasi hijau dari pada sebagai pusat konservasi tumbuhan. Keberadaannya dituntut untuk menjalankan visi menjadi salah satu kebun raya terbaik di dunia dalam bidang konservasi dan penelitian tumbuhan tropika, pendidikan lingkungan dan pariwisata.

Mengenai misi, Kebun Raya Bogor memiliki 10 misi, yaitu: Memperkuat bobot ilmiah di dalam pengelolaan koleksinya. Pertama, mengembangkan model pengelolaan tumbuhan secara ex situ dalam bentuk kebun raya. Kedua, melakukan pembinaan dan pengawasan teknis atas pembangunan kebun raya di Indonesia. Ketiga, meningkatkan mutu penelitian di bidang konservasi, domestikasi, ekonomi botani dan reintroduksi tumbuhan Indonesia. Misi keempat, yaitu melakukan diseminasi dan komersialisasi produk hasil penelitian. Kelima, Memperkuat manajemen kelembagaan menuju reformasi birokrasi, wilayah bebas dari korupsi (WBK) dan wilayah birokrasi bersih melayani (WBBM).

Misi keenam hingga kesepuluh Kebun Raya Bogor cukup relevan dengan penelitian ini, yaitu meningkatkan mutu pelayanan publik, termasuk mutu pendidikan lingkungan dan penyediaan informasi ilmiah, memperkuat jaringan kerjasama dengan para pemangku kepentingan, baik dari dalam maupun luar negeri, meningkatkan dan memperkuat capacity building sumber daya manusia, dan membangun dan mengembangkan sarana prasarana yang dibutuhkan, khususnya sarana prasarana yang menunjang pelayanan publik dan penelitian. Secara resmi, Kebun Raya Bogor memiliki 
tugas pokok, yaitu penyiapan bahan perumusan kebijakan, penyusunan pedoman, pemberian bimbingan teknis, penyusunan rencana dan program, pelaksanaan penelitian bidang konservasi ex-situ tumbuhan tropika serta evaluasi dan penyusunan laporan.

Jumlah kebun raya yang dikelola LIPI secara langsung juga masih belum banyak diketahui publik. Kebun raya yang dimaksud, yaitu Kebun Raya Bogor, Kebun Raya Cibodas, Kebun Raya Purwodadi, Kebun Raya 'Eka Karya' Bali, dan Kebun Raya Cibinong. Fungsi unit kerja LIPI ini juga belum familiar diketahui oleh publik. Secara ringkas, fungsi-fungsi kebun raya meliputi fungsi konservasi, penelitian, pendidikan, wisata dan jasa lingkungan.

Berdasarkan Peraturan Kepala LIPI nomor 1 tahun 2019, Pusat Konservasi Tumbuhan Kebun Raya memiliki fungsi melakukan perumusan dan pelaksanaan kebijakan bidang penelitian dan pengembangan kawasan Kebun Raya. Fungsinya yang ke dua adalah melakukan pemberian bimbingan teknis dan supervisi di bidang penelitian konservasi tumbuhan. Fungsi ketiga Kebun Raya Bogor adalah melakukan pengembangan kawasan Kebun Raya. Selain itu, juga melakukan pemantauan, evaluasi, dan laporan penelitian bidang konservasi tumbuhandan pengembangan kawasan kebun raya, serta pelaksanaan urusan tata usaha.

\section{METODE PENELITIAN}

Peristiwa yang dikaji dan dituliskan dalam artikel ini adalah peristiwa lampau, namun masih relevan untuk dijadikan referensi penelitian lainnya. Serangkaian metode penelitian mendukung kajian ini. Fenomena respon tim komunikasi krisis LIPI terhadap peristiwa tumbangnya pohon di Kebun Raya Bogor dan menyebabkan tewasnya tujuh orang pengunjung, dengan menggunakan paradigma konstruktivis.

Penelitian ini mengkonstuksi berbagai sudut pandang mengenai peristiwa tumbangnya pohon di Kebun Raya Bogor. Peristiwa tersebut merupakan sebuah realitas sosial yang dipahami sebagai suatu hal yang relatif dan kompleks, yang perlu dipahami dengan sebuah paradigma konstruktivis.

Penelitian ini dilakukan dengan pendekatan ilmiah kualitatif deskriptif. Creswell mendefinisikan metode kualitatif merupakan metode-metode untuk mengeksplorasi dan memahami makna oleh sejumlah individu atau sekelompok orang yang dianggap berasal dari masalah sosial atau kemanusiaan. Proses penelitian kualitatif ini melibatkan upaya-upaya penting, seperti mengajukan pertanyaan-pertanyaan dan prosedur-prosedur, mengumpulkan data yang spesifik dari partisipan, menganalisis data secara induktif 
mulai dari tema-tema yang khusus ke tema-tema umum, dan menafsirkan makna data (Creswell, 2016).

Penelitian ini membangun deskripsi peristiwa dari penafsiran makna data dan informasi yang disusun secara sistematis. Deskripsi dalam penelitian ini dijelaskan dalam bentuk kata-kata, bahasa, dan gambar sehingga bisa menjelaskan suatu realitas sosial.

Metode penelitian yang dilakukan yaitu studi kasus, Creswel mengatakan studi kasus merupakan kerangka penelitian khususnya evaluasi juga banyak ditemukan di bidang lainnya. Peneliti mengembangkan analisis mendalam atas suatu kasus, sering kali program, peristiwa, aktivitas, proses atau satu individu atau lebih (Creswel, 2009). Dalam penelitian ini, analisis difokuskan pada strategi komunikasi pada fase respon krisis.

Data primer penelitian ini adalah didapatkan dari observasi. Peneliti merupakan bagian dari tim komunikasi krisis sehingga mengetahui bagaimana dinamika, perumusan dan pengambilan keputusan komunikasi yang dilakukan manajemen. Observasi dalam penelitian ini termasuk dalam kategori observasi partisipan. Peneliti turut terlibat dalam penyelesaian krisis, khususnya dalam perancangan tindakan respon atas dampak peristiwa tumbangnya pohon di Kebun Raya Bogor.
Data sekunder diperoleh dengan studi dokumen dari pemberitaan-pemberitaan di media massa, cetak, online dan media sosial. Data pendukung lainnya diperoleh dengan wawancara terhadap informan kunci yaitu Rosniati Apriani Risna, M.Si selaku Kepala Subbagian Kerjasama dan Informasi Kebun Raya Bogor dan Isrard, S,H., M.H. selaku Kepala Bagian Humas Biro Kerjasama Hukum dan Humas LIPI pada masa peristiwa terjadi, yaitu pada tahun 2015 .

Meskipun peristiwa ini sudah berlalu, penelitian ini masih sangat relevan untuk menggambarkan kasus dalam konteks studi ilmiah. Penelitian ini berupaya menguatkan strategi komunikasi yang disusun secara korporat, khususnya dalam menghadapi krisis.

Sedangkan analisis data dilakukan dengan reduksi data, display data serta penarikan kesimpulan (Sugiyono, 2014). Reduksi data dalam penelitian ini dilakukan dengan meringkas setiap informasi yang ditemukan dari berbagai sumber, baik hasil pengamatan langsung maupun informasi dari berbagai pemberitaan di media massa eletronik dan media sosial terkait tumbangnya pohon di Kebun Raya Bogor. Kemudian data yang telah direduksi disajikan dalam bentuk narasi. Terakhir dilakukan penarikan simpulan. 


\section{HASIL DAN PEMBAHASAN}

Berdasarkan data dan informasi yang diperoleh dari hasil wawancara, observasi, dan dokumentasi, berikut ini adalah hasil penelitian dan pembahasan. Hasil dan pembahasa penelitian ini yang dibagi dalam uraian analisis krisis dan analisis respon krisis.

Analisis krisis adalah suatu langkah yang bertujuan memetakan permasalahan atas suatu kejadian guna mendapatkan keputusan untuk melakukan tindakan yang tepat. Analisis dalam penelitian ini salah satunya dilakukan terhadap pemberitaan mengenai tumbangnya pohon di Kebun Raya Bogor yang dimuat di media massa online.

Hasil analisis terhadap pemberitaan di media massa online yang tercatat sebanyak 45 pemberitaan dari 11-19 Januari 2015. Hari pertama kejadian yaitu tanggal 11 Januari 2011 media massa membingkai berita dengan hanya memaparkan kronologi peristiwa kejadian tumbangnya pohon dan mengangkat isu tentang jumlah korban.

Peneliti melihat jenis krisisnya merupakan Victim cluster. Berdasarkan analisis jenis krisis victim cluster, dapat disimpulkan bahwa Kebun Raya Bogor dianggap sebagai korban, di mana kejadian pohon tumbang tersebut merupakan bencana alam yang tidak terduga.

Tumbangnya pohon damar diduga karena rayap, di mana terjadi pelapukan di dalamnya. Kepala sub bidang pemeliharaan koleksi Izu Andri mengatakan secara kasat mata pohon damar tersebut nampak sehat. Namun ternyata mengalami kebusukan di dalam batangnya. Selain itu pohon tersebut sudah sangat tua yakni diperkirakan berumur 50 tahun.

Pemberitaan tersebut diatas juga dikuatkan oleh pernyataan Kepala Subbagian Kerjasama dan Informasi Rosniati Apriani Risna. Hasil analisis yang dilakukan oleh salah seorang ahli rayap yang diminta sebagai ahli oleh pihak Kebun Raya Bogor menduga rayap tanah jenis Coptotermes $s p$. merupakan faktor penggangu yang menyebabkan kelapukan pada pohon damar, sehingga tumbang dan menimbulkan korban jiwa.

"Rayap Coptotermes sp. umumnya bagian akar yang pertama kali diserang dan terus naik hingga ke batang dan pucuk. Selain itu perilaku hidupnya yang kriptobiotik menyebabkan kondisi kerusakan pohon sulit dideteksi secara dini." (Risna, 4 September 2020. Wawancara melalui saluran komunikasi pribadi).

Bukti lain yang menguatkan bahwa tumbangnya pohon Agathis dammara sebagai akibat dari aktivitas serangan rayap karena saat kejadian cuaca disekitar dan area kebun raya cerah, sama sekali tidak ada angin kencang maupun hujan lebat yang biasanya berpotensi menumbangkan pohon-pohon di Kebun Raya Bogor. Hal ini seperti terlihat dalam kalimat pemberitaan yang dimuat antaranews.com 
tanggal 11 Januari 2015 beberapa jam setelah kejadian. Berikut kutipannya:

Tanpa ada hujan maupun angin, pohon yang berdiameter sekitar 1 meter dan panjang 8 meter tersebut patah dan menimpa tenda tempat karyawan mengisi kegiatan. (Rahmawati, 2015).

Selain itu juga terdapat pada pemberitaan yang dimuat oleh republika.co tanggal 11 Januari 2015 beberapa saat setelah kejadian, berikut kutipannya :

"Meski cuaca cerah, tidak menutup kemungkinan pohon yang rapuh dapat tumbang karena sebelumnya hujan dan angin terus melanda," kata Usmar, Ahad (11/1) (Wulandari, 2015).

Dua kutipan terakhir disinyalir diambil dari pernyataan pengunjung melalui wawancara yang dilakukan oleh media. Kedua kutipan menggambarkankondisicuaca yang sebelumnya turun hujan dan memungkinkan menjadi penyebab tumbangnya pohon damar tersebut. Selanjutnya, dari penjelasan narasumber yang juga dikutip oleh media di atas, karakteristik serangan rayap seperti di atas cukup dipahami bila serangga perusak ini (rayap) digolongkan dalam UU No 28 Tahun 2002 tentang Bangunan Gedung sebagai bagian dari perilaku alam yang seringkali sudah dimitigasi namun dapat masih terjadi kejadian serangan rayap pada bangunan gedung (Risna, 2015b).

"Hal ini juga dikuatkan oleh argumentasi Kepala Bagian Humas Biro Kerjasama Hukum dan Humas LIPI Isrard S.H., M.H. menurutnya tumbangnya pohon tersebut karena faktor alam yang tidak bisa di duga dan diantisipasi sehingga pantasnya kejadian tersebut termasuk dalam kategori Force Majeure. "Force Majeure biasanya dalam kerja sama yang mengecualikan kondisi karena keadaan diluar batas kendali manusia. Untuk kasus di Kebun Raya Bogor lebih tepat karena ada musibah kecelakaan". (Isrard, 3 September 2020, Wawancara melalui saluran komunikasi pribadi).

Menurut Black's Law Dictionary, force majeur adalah "an event or effect that can be neither anticipated nor controlled". Secara gamblang dan rinci, kondisi force majure memang belum diatur dalam tatanan hukum perdata materiil Indonesia. Kitab Undang-Undang Hukum Perdata, Pasal 1245 menjelaskan bahwa ketika suatu kondisi yang dihadapi berada dalam keadaan memaksa (overmacht), maka salah satu pihak yang berada dalam suatu hubungan kerja sama tidak diwajibkan membayar ganti rugi terhadap pihak lainnya.

Dari kedua ketentuan tersebut terdapat kesamaan yaitu salah satu pihak yang berada dalam suatu hubungan kerjasama tidak dapat menanggung beban karena kondisi diluar kendali sebagai bagian dari faktor-faktor diluar kesepakatan (Siregar, Putra PM Zahra, 2020). Isi pemberitaan di media massa di hari berikutnya sudah mulai menyasar tentang aktor yang mesti bertanggung jawab atas terjadinya korban. Dalam hal ini pemberitaan mulai 


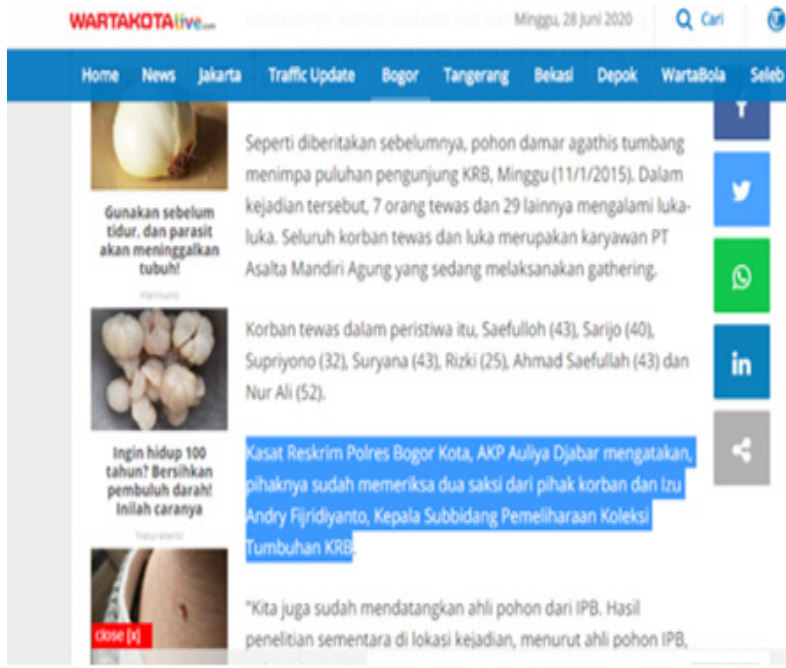

Sumber: Wartakota, 2015

Gambar 1 Pemberitaan tentang Polisi Gandeng Ahli IPB

mengarah pada pembentukan opini bahwa telah terjadi kelalaian dalam melakukan pengawasan dan perawatan koleksi tanaman di Kebun Raya Bogor. Di sinilah krisis mulai muncul ke permukaan.

Berikut ini merupakan pemberitaan di media massa online yang mulai menyinggung aktor yang harus bertanggungjawab terhadap peristiwa tumbangnya pohon yang dimuat pada tanggal 15 Januari 2015. Berikut tulisannya:

"Kasat Reskrim Polres Bogor Kota, AKP Auliya Djabar mengatakan, pihaknya sudah memeriksa dua saksi dari pihak korban dan Izu Andry Fijridiyanto, Kepala Subbidang Pemeliharaan oleksi Tumbuhan KRB. "Kepada penyidik dia menjelaskan, selama ini pohon di Kebun Raya selalu menjalani pemerisaan rutin, meskipun secara visual, termasuk pohon damar. Pohon itu terakhir diperiksa 5 januari lalu," katanya. (Henaldi, 2015)

Selain itu terbit juga pemberitaan yang mengarah pada pembentukan opini. Berikut ini adalah bukti pemberitaan bahwa telah terjadi kesalahan pengelolaan oleh manajemen Kebun Raya Bogor, pada gambar 2.

Atas dasar tersebut peneliti memasukan krisis ini ke dalam Preventabel cluster. Berdasarkan analisis, diketahui bahwa kondisi ini selaras dengan pendapat pakar yang menyatakan bahwa organisasi dengan sengaja menempatkan orang dalam risiko, mengambil tindakan yang tidak pantas atau melanggar hukum / peraturan (T. Coombs, 2007) . Kepala sub bagian kerjasama dan informasi Rosniati Apriani Risna mengatakan bahwa pengawasan dan perawatan koleksi di Kebun Raya Bogor sudah mengikuti SOP. SOP tersebut menjadi panduan bagi perawat dan pengawas koleksi

\section{Polisi Selidiki Faktor Kelalaian dalam Peristiwa Kebun Raya Bogor}

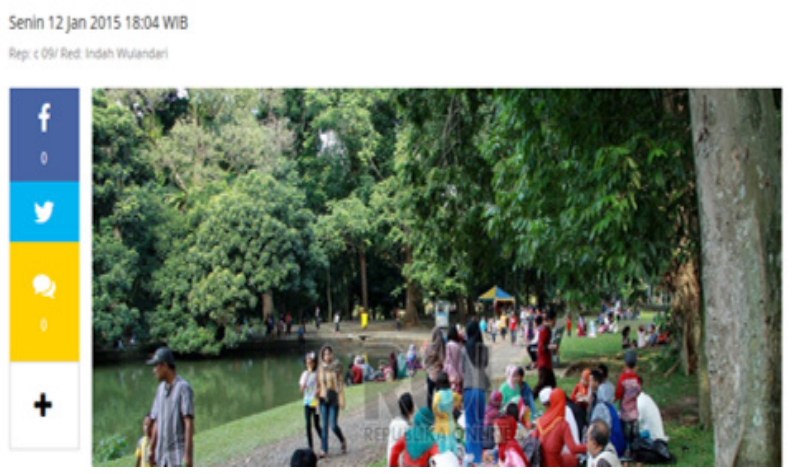

Sumber: Republika, 2015

Gambar 2 Pemberitaan Isu Pohon Tumbang di Kebun Raya Bogor Meluas ke Ranah Hukum 
tumbuhan dan telah terdokumentasikan.

"Tim perawat koleksi di lokasi kejadian sudah mengikuti SOP merawat dan melaporkan kondisi tanaman secara periodik kepada atasannya Kasubid Pemeliharaan koleksi. Berdasarkan laporan tim, tidak ditemukan indikasi pohon tidak sehat." (Risna, 4 September 2020, Komunikasi Pribadi).

Dalam sebuah wawancara, narasumber memberikan pernyataan bahwa jika keputusan pengadilan menetapkan kasus tersebut sebagai tindakan pidana, maka ini akan menjadi asas presedent (yurisprudensi) yang akan menghantui setiap insan yang bekerja di seluruh kebun raya di Indonesia. Khususnya tenaga lapangan, dan menjadi kerikil tajam bagi upaya pembangunan kebun raya di Indonesia yang sekarang sedang giat-giatnya. Ironi di tengah perjuangannya menyelamatkan aset bangsa ini dihantui bayang-bayang gelapnya tembok penjara (Risna, 2015b)

Pada beberapa kasus, termasuk kasus pohon tumbang di Kebun Raya Bogor, waktu yang tersedia untuk menangani krisis sangat sempit karena krisis terjadi dalam waktu yang cepat serta menarik banyak perhatian publik. Munculnya tekanan dari pihak korban dan intervensi dari beberapa pihak lain yang memiliki kompetensi di bidang pengelolaan tanaman juga menerpa manajemen.

Berdasarkan waktu terjadinya krisis, dengan demikian, tipe krisis seperti ini merupakan tipe immediate crisis, atau krisis yang bersifat segera. Cutlip mengatakan Immediate crisis adalah tipe krisis yang paling ditakuti, karena krisis yang terjadi muncul secara tiba-tiba sehingga organisasi tidak mempunyai waktu untuk melakukan perencanaan riset (Cutlip et al., 2013). Tipe krisis ini datang dikarenakan salah satunya adanya bencana yang terjadi dan berdampak pada organisasi. Berdasarkan analisis, temuan dalam penelitian terkait tumbangnya pohon di Kebun Raya Bogor termasuk ke dalam jenis krisis Victim Cluster dan jenis krisis Preventable Cluster (Coombs, 2007).

Strategi respon krisis perlu dilakukan guna menyelamatkan reputasi lembaga dari citra negatif di media massa. Manajemen Kebun Raya Bogor segera menerapkan manajemen komunikasi krisis untuk mengatasi masalah yang terjadi.

Metode kerja Humas LIPI sebagai back up management dalam menyelesaikan krisis selaras dalil bahwa upaya mengatasi krisis yang dilakukan oleh tim public relations berpegang pada etika. Dengan berpegang pada etika, kerja Humas mengakselerasi selesainya permasalahan (Indrayani, 2017).

Pada hari pertama Minggu 11 Januari 2015, strategi manajemen yang dilakukan yaitu dengan memberikan penanganan segera terhadap seluruh korban luka-luka untuk dilakukan proses penanganan medis dengan dibawa ke 
Rumah Sakit PMI Kota Bogor. Manajemen Kebun Raya Bogor menanggung semua biaya perawatan korban serta memberikan santunan kepada keluarga korban yang cacat permanen dan meninggal dunia sesuai dengan premi asuransi yang dibayar melalui tiket masuk.

Adapun strategi komunikasi krisis yang dilakukan di hari pertama, tim Humas dari sub bagian kerjasama informasi mendampingi proses wawancara media kepada Kepala Kebun Raya Bogor. Selain mendampingi Kepala Kebun Raya Bogor, tim Humas juga membantu menyiapkan data dukung dan menjaga agar narasumber utama tidak terjebak dengan pertanyaan-pertanyaan wartawan yang justru akan merugikan lembaga.

Berikutnya, strategi yang dilakukan adalah rebuild crisis response strategies dengan memberikan kompenasasi (compensation) berupa santunan terhadap keluarga korban yang meninggal dunia, serta biaya perawatan sampai sembuh kepada korban yang mengalami lukaluka. Selain itu, pihak Kebun Raya Bogor memberikan biaya pendidikan kepada anak dari orang tua yang meninggal dunia, juga memberikan dana untuk membangun usaha serta menjadikan salah satu anggota keluarganya sebagai pegawai honorer di lingkungan Kebun Raya Bogor.

Upaya lain dari manajemen Kebun Raya Bogor adalah menyampaikan permintaan maaf (apology) juga dilakukan oleh manajemen kepada korban yang luka-luka serta keluarga korban yang meninggal dunia. Ungkapan apology ini dilakukan dengan mengutus pejabat struktural menemui keluarga korban khususnya yang meninggal dunia di kediamannya masingmasing serta menyampaikan secara terbuka kepada media massa. Krisis yang dapat dicegah memiliki efek paling negatif pada reputasi organisasi. Strategi pembangunan kembali (rebuild crisis response strategies) adalah cara pemulihan reputasi yang paling tepat. Selain itu, semakin parah orang menilai suatu krisis, semakin negatif persepsi mereka terhadap reputasi suatu organisasi. Efek interaksi antara tipe krisis dan strategi respons krisis terhadap reputasi perusahaan tidak signifikan (Claeys A et al., 2010).

Langkah selanjutnya adalah rapat pimpinan struktural. Pada pertemuan pimpinan ini dibentuk tim khusus untuk menyelesaikan krisis dengan melakukan komunikasi krisis. Krisis yang timbul merupakan krisis yang tidak selesai dalam waktu singkat, namun terus berlanjut.

Untuk menangani komunikasi krisis, tim di pimpin oleh kepala sub bagian kerjasama dan informasi Rosniati Apriani Risna yang dibantu oleh fungsional pranata humas di lingkungan Kebun Raya Bogor. Adapun tugas yang diembannya yaitu melakukan analisis isi terhadap pemberitaan di media massa baik cetak 


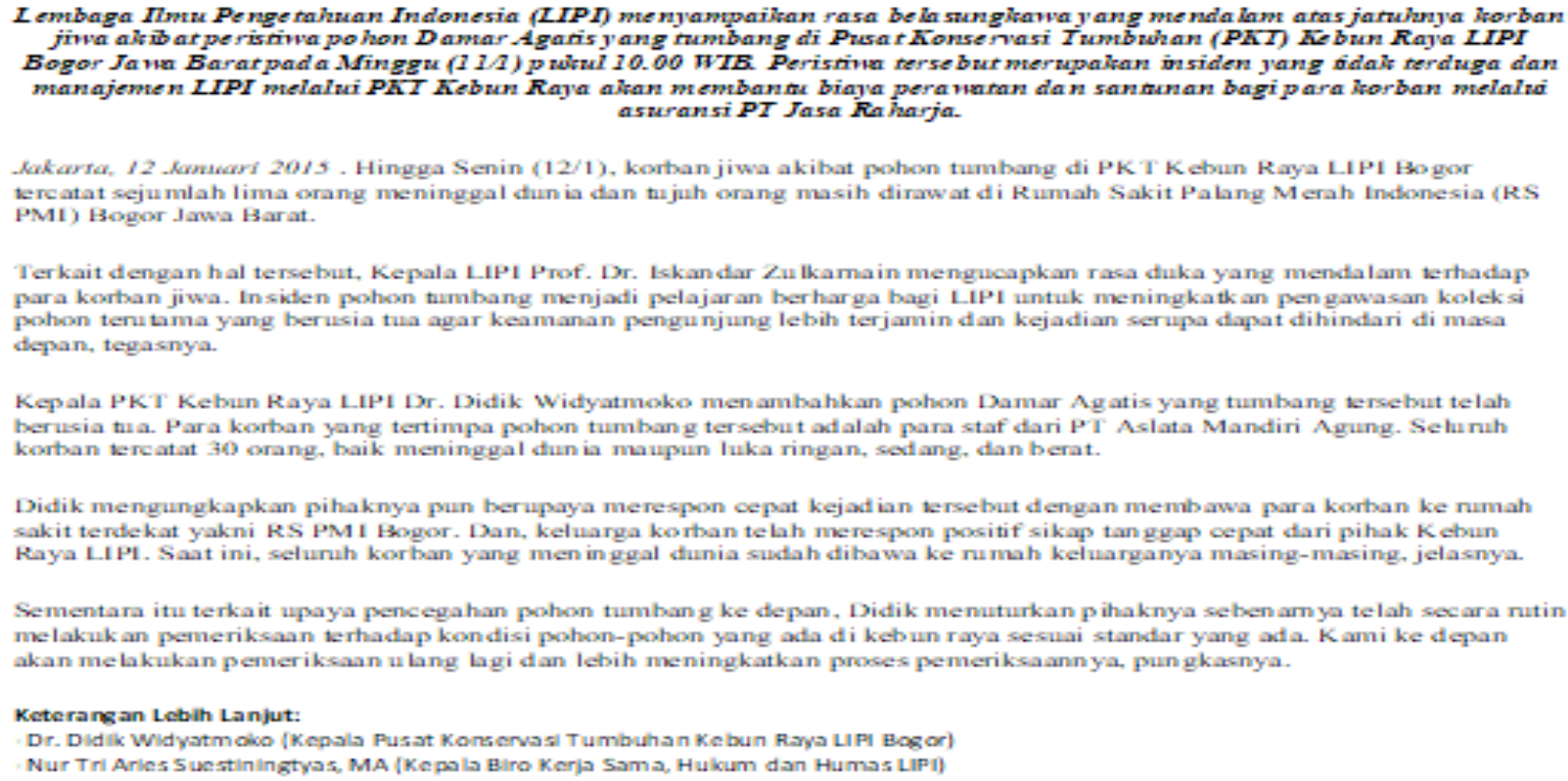

Kakarra, 12 Konwari 2015. Hingga Senin (12/1), korban jiwa akibat pohon tumbang di PK T Kebun Raya L. P1 Bogor tercatat sejumlah lima orang meninggal dunia dan tujuh orang masih dirawat di Rumah Sakit Palang Merah Indonesia (RS PMI) Bogor Jawa Barat.

Terkait dengan hal tersebut, Kepala LIP1 Prof. Dr. Lskandar Zulkamain mengucapkan rasa duka yang mendalan terhadap para korban jiwa. Insiden pohon tumbang nenjadi pelajaran berharga bagi LIPI untuk meningkatkan pengawasan koleks pohon teru tama yang berusia tua agar keamanan pengunjung lebih terjamin dan kejadian serupa dapat dihindari di masa depan, tegasnya.

Kepala PKT Kebun Raya LIPI Dr. Didik Widyatmoko menambahkan pohon Damar Agatis yang tumbang tersebut telah berusia tua. Para korban yang tertimpa pohon tumbang tersebut adalah para staf dari PT Aslata Mandiri Agung. Selu nuh korban tercatat 30 orang, baik meninggal dun ia maupun luka ringan, sedang, dan berat.

Didik mengungkapkan pihaknya pun berupaya merespon cepat kejadian tersebut dengan membawa para korban ke numah sakit terdekat yakni RS PMI Bogor. Dan, keluarga korban telah merespon positif sikap tan ggap cepat dari pihak Kebur Raya LIP1. Saat ini, selunuh korban yang men in ggal dunia sudah dibawa ke numah keluarganya masing-masing, jelasnya.

Sementara itu terka it upaya pencegahan pohon tumbang ke depan, Didik menuturkan pihaknya seben arnya telah secara rutin melakukan peneriksaan terhadap kondisi pohon-pohon yang ada di kebun raya sesuai standar yang ada. Kami ke depan akan melakukan pemeriksaan u lang lagi dan lebih meningkatkan proses pemeriksaannya, pungkasnya.

Keterangan Lebilh Lanjut:

Dr. Didik Widyatmolico (Kepala Pusat Konservasl Tumbuhan Kebun Raya LIPI Eogor)

Nur Tri Aries Suestiningtyas, MA (Kepola Biro Kerja Sama, Hukum dan Humas LIP1)

Sumber: Website LIPI, 2015

Gambar 3 Siaran Pers Mengenai Belasungkawa LIPI terhadap Korban Pohon Tumbang di Kebun Raya Bogor.

maupun elektronik yang salah satu fungsinya sebagai dasar dalam penyusunan pesan kunci (key messages) lembaga. Analisis isi media harus dilakukan oleh humas pemerintah terutama saat mengalami krisis. Hal ini sebagai saran masukan dan evalusi dalam perencanaan jangka panjang manajemen krisis (Ulfa et al., 2019)

Pesan kunci juga dibuat dalam bentuk siaran pers agar lebih mudah diangkat oleh media massa. Siaran pers ini dikeluarkan oleh bagian humas di Biro Kerja sama Hukum dan Hubungan Masyarakat LIPI dan diunggah melalui website dan media sosial lembaga menjadi pesan kunci sebagai jawaban atas krisis yang terjadi. Siaran pers yang dikeluarkan
Bagian Humas LIPI pada tanggal 12 Januari 2015 menitikberatkan pada sikap empati dan rasa belasungkawa seluruh civitas LIPI yang diungkapkan langsung oleh Kepala LIPI Prof Dr. Iskandar Zulkarnain terhadap keluarga korban (FZA, 2015).

Strategi dalam pemilihan pesan ini, sangat efektif dalam menurunkan tensi pemberitaan yang cenderung negatif di hari sebelum LIPI mengeluarkan siaran pers ini. Terbukti pada beberapa pemberitaan media yang mengutip siaran pers ini sebagai isi dalam pemberitaannya. Selain itu, sikap respon cepat manajemen Kebun Raya Bogor dalam menangani para korban di Rumah Sakit, serta bertanggung jawab untuk seluruh biaya perawatan serta 
memberikan santunan yang disampaikan kepada media massa. Hal ini telah memberikan penyeimbangan dalam pemberitaan, sehingga tidak semua pemberitaan yang dimuat media massa bertendensi negatif.

Agar tidak terjadi kesimpangsiuran informasi manajemen Kebun Raya Bogor menunjuk tiga nasumber sebagai komunikator kunci dalam memberikan informasi kepada media massa. Ketiga narasumber tersebut yaitu Kepala Pusat Konservasi Tumbuhan Kebun Raya LIPI, Kepala Subbagian Kerjasama dan Informasi serta staf Pranata Humas muda di lingkungan Kebun Raya Bogor.

Manajemen Kebun Raya Bogor juga melakukan audiensi dengan Dewan Perwakilan Rakyat Daerah (DPRD) Kota Bogor. Dalam audiensi yang diterima oleh Ketua DPRD Kota Bogor Untung Maryono tersebut, Manajemen Kebun Raya Bogor LIPI memaparkan kondisi terkait penanganan terhadap korban baik yang di rawat di RS PMI maupun keluarga korban yang meninggal. Selain itu juga disampaikan SOP dalam menangani pohon-pohon koleksi di Kebun Raya Bogor.

Manajemen Kebun Raya Bogor mencoba mengingatkan kembali kepada stakholders dalam hal ini DPRD Kota Bogor terkait hubungan baik di masa sebelum krisis. Kebun Raya Bogor LIPI dengan Pemkot Bogor sudah menandatangani kerja sama terkait pengelolaan di sekitar area Kebun Raya Bogor yang dilakukan oleh Pemerintah Kota (Pemkot) Bogor, dalam perjanjian tersebut Pemkot Bogor menerima dana retribusi sebesar $\mathrm{Rp} 1.000$ (seribu rupiah) dari setiap tiket yang terjual.

Berdasarkan analisis, manajemen Kebun Raya Bogor menerapkan bolstering crisis response strategies. Strategi ini merupakan strategi tambahan yang bisa dilakukan oleh organisasi, tujuannya membangun sikap empati dari stakeholders atau pihak yang merasa dirugikan dengan terjadinya krisis sehingga tercipta hubungan baik antara organisasi dengan stakeholders atau pihak yang merasa dirugikan (Coombs, 2007).

Upaya respon krisis lainnya yaitu dengan mengimbangi isu negatif dengan berita berisi isu positif lembaga. Hal ini dilakukan dengan cara mem-blasting berita terkait capaiancapaian kinerja lembaga, misalnya dengan mengirimkan artikel ke Media Indonesia tentang penemuan jenis baru Begonia di Halmahera hasil eksplorasi penelitian Wisnu Handoyo Ardi sehingga diharapkan bisa menjadi penyeimbang isu (Anonim, 2015).

Upaya memperlemah hubungan organisasi dengan krisis dilakukan dengan melakukan rencana kontingensi. Menurut (Loven et al., 2020) rencana kontingensi dilakukan dengan cara melanjutkan aktivitas selama krisis, namun organisasi tetap melakukan strategi untuk 
memperbaiki keadaan pasca krisis. Rencana kontingensi dilakukan dalam dua hal, yakni perbaikan manajemen secara internal dan eksternal. Perbaikan internal dilakukan antara lain dengan melakukan manajemen resiko, untuk mencegah krisis yang sama terulang kembali sekaligus untuk mengembalikan kepercayaan publik pada lembaga. Perbaikan manajemen secara eksternal dengan instens menjalin komunikasi dengan stakeholders.

"Manajemen krisis juga dilakukan oleh Kebun Raya Bogor dengan melibatkan technical support dari ahli tumbuhan. Hal ini untuk mengimbangi isu negatif dari pemberitaan di media terkait adanya kelalaian dalam penangan koleksi pohon" (Risna, 4 September 2020, Wawancara melalui saluran komunikasi pribadi).

Dalam proses penanganan sebuah resiko, Hendriyani membagi pada tiga aspek yaitu risk management, risk assessment dan risk communication. Risk assessment bertujuan untuk mengidentifikasi berbagai macam resiko yang akan dan telah terjadi (Hendriyani et al., 2016). Kebun Raya Bogor berupaya untuk meningkatkan keamanan pengunjung dengan melakukan pengecekan kesehatan pohon. Pengecekan pohon ini dilakukan oleh penelitipeneliti Kebun Raya Bogor. Hasil pengecekan ini menjadi dasar untuk mengklasifikasikan perawatan dan penanganan pohon berdasarkan usia dan karakteristik untuk mencegah potensi pohon tumbang.

Risk management lebih menekankan pada langkah-langkah proses manajemen dalam hal menanggulangi keadaan (Hendriyani et al., 2016). Sedangkan Yoe mengatakan manajemen resiko sebagai proses identifikasi masalah, meminta informasi, mengevaluasi risiko, dan memulai tindakan untuk mengidentifikasi, mengevaluasi, memilih, menerapkan, memantau, dan memodifikasi tindakan yang diambil untuk mengubah tingkat risiko yang tidak dapat diterima menjadi diterima atau tingkat yang dapat ditoleransi (Yoe, 2019).

Risk management dilakukan dengan tetap membuka akses bagi pengunjung untuk berkunjung, namun memberlakukan sistem zonasi, yaitu mengklasifikasikan area-area mana yang rawan dan mana yang aman untuk dikunjungi pengunjung kebun raya. Manajemen Kebun Raya Bogor melakukan audiensi dengan mantan-mantan Kepala Kebun Raya tujuannya mengkomunikasikan perkembangan krisis serta mencari alternatif solusi dalam penangan krisis. Sedangkan risk communication yang dilakukan adalah dengan memberikan pernyataan mengenai langkah-langkah yang dilakukan manajemen Kebun Raya Bogor terkait risk assesment dan risk management untuk mencegah hal yang sama terulang kembali di masa depan. 
Tabel 1 Analisis Krisis dan Strategi Respon Krisis Tumbangnya Pohon di Kebun Raya Bogor

\begin{tabular}{|c|c|c|c|c|}
\hline No & Isu & Jenis Krisis & $\underset{\text { Krisis }}{\text { Strategi Respon }}$ & Strategi Aksi \\
\hline 1 & $\begin{array}{l}\text { Tu m b a n g n y a } \\
\text { Pohon di Kebun } \\
\text { Raya sebagai } \\
\text { peristiwa bencana } \\
\text { alam }\end{array}$ & Victim Cluster & $\begin{array}{ll}\text { Rebuild } & \text { Crisis } \\
R \text { es p o n s e } \\
\text { Strategies }\end{array}$ & $\begin{array}{l}\text { Strategi dengan pemberian } \\
\text { kompensasi dan permintaan } \\
\text { maaf terhadap korban dan } \\
\text { keluarga korban }\end{array}$ \\
\hline 2 & $\begin{array}{l}\text { Adanya indikasi } \\
\text { kelalaian dalam } \\
\text { pengawasan dan } \\
\text { perawatan koleksi } \\
\text { tumbuhan di kebun } \\
\text { raya }\end{array}$ & $\begin{array}{l}\text { Preventabel } \\
\text { Cluster }\end{array}$ & $\begin{array}{l}\text { Bols tering } \\
\text { Crisis Response } \\
\text { Strategies }\end{array}$ & $\begin{array}{l}\text {-Berkoordinasi dengan } \\
\text { DPRD Kota Bogor; } \\
\text { - Blasting pemberitaan positif; } \\
\text { - Kebun Raya Bogor tetap di } \\
\text { buka (strategi kontingensi) }\end{array}$ \\
\hline
\end{tabular}

Sumber: Data diolah peneliti, 2020

Manajemen Kebun Raya Bogor Raya Bogor yang lebih dikenal sebagai menugaskan bagian keamanan untuk selalu tempat wisata sebenarnya secara resmi menginformasikan untuk menjauhi area yang memiliki fungsi-fungsi yang lebih lengkap, berpotensi pohon tumbang, membuat spanduk yaitu sebagai kawasan konservasi, penelitian, informasi serta membuat zona area yang pendidikan, wisata dan jasa lingkungan. tidak boleh ada aktivitas pengunjung juga Implementasi manajemen Kebun Raya Bogor memasang rambu-rambu terkait koleksi pohon di area Kebun Raya Bogor (Kristyarini, 2015). Tujuan dilakukannya risk communication ini adalah untuk mengembalikan citra lembaga dan mengembalikan kepercayaan publik pada lembaga.

Berdasarkan hasil penelitian, berikut ini adalah ringkasan pembahasan yang dikemas dalam tabel 1.

\section{SIMPULAN}

Simpulan pertama mengenai penegasan pada fungsi-fungsi Kebun Raya Bogor. Kebun dalam menjalankan fungsinya adalah dengan memerhatikan kondisi aset termasuk tanaman langka dan koleksi yang ada di Kebun Raya Bogor.

Peristiwa tumbangnya pohon di Kebun Raya Bogor pada 2015 silam melahirkan sebuah krisis. Krisis yang terjadi akibat tumbangnya pohon Agathis dammara di Kebun Raya Bogor LIPI termasuk ke dalam dua jenis krisis yaitu, victim cluster dimana Kebun Raya Bogor LIPI menjadi korban karena krisis terjadi akibat bencana alam. Selain itu juga masuk ke dalam Preventable cluster dimana krisis terjadi akibat 
kelalaian yang berkonsekuensi hukum.

Strategi respon krisis yang dilakukan manajemen Kebun raya Bogor adalah Rebuild Crisis Response Strategies. Strategi tersebut dilakukan dengan memberikan kompensasi perawatan, uang santunan dan juga permintaan maaf terhadap korban. Strategi lain yang dilakukan adalah Bolstering Crisis Response Strategies yaitu dengan mengingatkan stakeholders akan hubungan baik sebelum krisis.

Dalam proses penanganan sebuah resiko, Tim komunikasi krisis melakukan risk management, risk assessment dan risk communication. Tim komunikasi krisis terdiri dari humas, kerja sama dan informasi, ahli tumbuhan, dan pimpinan unit kerja maupun pimpinan tertinggi LIPI saat itu.

Risk assessment telah dilakukan dengan maksud mengidentifikasi berbagai macam resiko yang akan dan telah terjadi dari peristiwa tumbangnya pohon di Kebun Raya Bogor. Risk management fokus menekankan pada serangkaian upaya dalam proses penanggulanagn masalah yang dilakukan oleh manajemen LIPI, khususnya Kebun Raya Bogor, dan risk communication yang dilakukan adalah dengan memberikan pernyataan yang menjelaskan berbagai langkah upaya yang dilakukan manajemen Kebun Raya Bogor kepada publik, atas peristiwa yang telah terjadi.
Upaya humas LIPI sebagai tim komunikasi krisis dalam merespon krisis adalah menyusun dan menerbitkan siaran pers yang dikeluarkan oleh tim humas dari biro kerjasama hukum dan humas LIPI. Konsep siaran pers disiapkan oleh sub bagian kerjasama dan informasi sebagai koordinator.

Dalam komunikasi krisis tersebut, sub bagian kerjasama dan informasi bertugas menganalisis isu, menyusun pesan kunci dan menjadi narasumber di berbagai media massa. Upaya ini dinilai telah berhasil meminimalisir isu pemberitaan yang negatf.

Sebagai upaya penyeimbang isu, biro kerjasama hukum dan humas LIPI bekerja sama dengan Pusat Konservasi Tumbuhan Kebun Raya Bogor mengemas pesan mengenai capaian-capaian lembaga dan memviralkannya. Capaian-capaian tersebut yang salah satunya berupa hasil penelitian juga dilakukan guna mengisi ruang pemberitaan.

Sebagai langkah antisipasi untuk mencegah hal yang sama terulang kembali, manajemen Kebun Raya Bogor melakukan manajemen resiko dengan cara melakukan pengecekan kesehatan pohon dengan melibatkan para peneliti, membuat klastering wilayah pohon berdasarkan usia dan karakteristik, membuat sistem zonasi area mana yang aman dan rawan untuk pengunjung, dan pemasangan ramburambu keselamatan di dalam area kebun raya. 


\section{DAFTAR PUSTAKA}

Akhyar, D. M., \& Pratiwi, A. S. (2019). Media sosial dan komunikasi krisis : pelajaran dari industri telekomunikasi di Indonesia. Jurnal Ilmu Komunikasi ULTIMACOMM, 11(1), 35-52.

Anonim. (2015). Dua begonia baru ditemukan di Halmahera. Media Indonesia.

Bempah, R. T. (2015). Kesaksian korban pohon tumbang di kebun raya bogor, 4 orang tewas. Kompas.Com. https://megapolitan. kompas.com/read/2015/01/11/14311261/ Kesaksian.Korban.Pohon.Tumbang. di.Kebun.Raya.Bogor.4.Orang.Tewas

Claeys A, S., Cauberghe, V., \& Vyncke, P. (2010). Restoring reputations in times of crisis: an experimental study of the situational crisis communication theory and the moderating effects of locus of control. Public Relations Review, 36(3), 256-262. https://doi. org/10.1016/j.pubrev.2010.05.004

Coombs, W. Timothy \& Holladay, S. J. (2010). The handbook of crisis communication. In The Handbook of Crisis Communication. https://doi.org/10.1002/9781444314885. $\operatorname{ch} 27$

Coombs, T. (2007). Protecting organization reputations during a crisis: the development and application of situational crisis communication theory. Corporate Reputations, 10(3), 163-176. https://doi. org/0.1057/palgrave.crr.1550049

Creswel, J. W. (2009). Research design: qualitative, quantitative, and mixed methods approaches. New York: SAGE Publications.

Creswell, J. W. (2016). Research design pendekatan kualitatif, kuantitatif, dan campuran. Yogyakarta: Pustaka Pelajar.
Cutlip, Center, \& Broom. (2013). Effective public relations (elevent). Pearson Education Limited.

De Wolf, D., \& Mohamed, M. (2013). Crisis management: lessons learnt from $b p$ deepwater horizon spill Oil. Business Management and Strategy, 4(2), 67-90.

Fearn-Banks, K. (2007). Crisis communications: A casebook approach. In Public Relations Review (Third Edit, Vol. 25, Issue 1). Mahwah, NJ: Lawrence Erlbaum Associates. https://doi.org/10.1016/s03638111(99)80136-2

FZA. (2015). Belasungkawa lipi terhadap korban pohon tumbang di Kebun Raya Bogor. LIPI.

Henaldi, S. (2015). Polisi gandeng ahli ipb teliti pohon tumbang.

Hendriyani, Parady, V., Ahsan, A., \& Radjiman S, D. (2016). Panduan komunikasi resiko keamanan pangan di saat krisis.

Indrayani, H. (2017). Etika Advokasi public relations dalam manajemen krisis reputasi. Interaksi: Jurnal Ilmu Komunikasi. https:// doi.org/10.14710/interaksi.5.1.68-77

Junita, N. (2017). Pohon berusia 194 tahun di kebun raya bogor tumbang.

Kristyarini. (2015). Pengunjung kebun raya diminta hindari pohon rawan tumbang. Kompas.

Kriyantono, R. (2012). Public relation dan crisis management: pendekatan critical public relations etnografi kritis dan kualitatif. In Salemba Humanika. Jakarta : Kencana.

Kriyantono, R. (2019). Research strategies and media relations in public relations practices. Jurnal Komunikatif, 8(2).

Lipi. (2015). Belasungkawa lipi terhadap korban pohon tumbang di kebun raya Bogor. http:// lipi.go.id/berita/single/BelasungkawaLIPI-Terhadap-Korban-Pohon-Tumbang- 
di-Kebun-Raya-Bogor/13795

Loven, D. P., Christin, M., \& Ayub. (2020). Crisis management strategy public relations of pt kai commuter jabodetabek on handling $\mathrm{krl}$ cross accident JakartaBogor. Journal of Media Communication Science, 3(1), 47-57.

Prastya, N. (2011). Komunikasi krisis di era new media dan social media. Jurnal Komunikasi, 6(1), 1-20.

Rahmawati, L. (2015). Seorang lagi korban pohon tumbang Kebun Raya Bogor meninggal. Anataranews.

Republika. (2015). Polisi selidiki kelalaina dalam peristiwa kebun raya Bogor. https:// www.republika.co.id/berita/nasional/ hukum/15/01/12/ni29f4-polisi-selidikifaktor- kelalaian-dalam-peristiwa-kebunraya-bogor

Risna. (2015a). Laporan internal pusat konservasi tumbuhan Kebun Raya LIPI.

Risna, R. A. (2015b). Laporan internal pusat konservasi tumbuhan Kebun Raya LIPI Tahun 2015. In Arsip.

Siregar, Putra PM Zahra, A. H. (2020). Bencana nasional penyebaran covid-19 sebagai alasan force majeure, apakah bisa? Keuangan, Direktorat Jenderal Kekayaan Negara Kementerian.

Sugiyono.(2014). Metode penelitian pendidikan pendekatan kuantitatif, kualitatif, dan $r \& d$.
Bandung: Alfabeta.

Suharyanti, \& Sutawidjaya H, A. (2012). Analisis krisis pada organisasi berdasarkan model anatomi krisis dan perspektif public relationS. Journal Communication Spectrum, 2(2), 165-185.

Suryani, I., \& Sagiyanto, A. (2018). Strategi manajemen krisis public relations pt blue bird group. Communication, 9(1), 102-113. Ulfa, N., Suadnya, W., \& Khusnia N, H. (2019). Manajemen krisis humas pemerintah daerah kabupaten Lombok Utara pada saat gempa bumi Lombok 2018. Journal of Media and Communication Science, 2(2), 97-115.

Wartakota. (2015). Polisi gandeng ahli ipb teliti pohon tumbang. https://wartakota. tribunnews.com/2015/01/16/polisigandeng-ahli-ipb-teliti-pohon-tumbang

Wulandari, I. (2015). Cuaca tak menentu, pohon di Kebun Raya Bogor rawan tumbang. Republika.

Yoe, C. (2019). Principles of risk analysis. in principles of risk analysis. CRC Press Taylor \& Francis Group. https://doi. org/10.1201/9780429021121

Yulianti, W., \& Boer F, R. (2020). Manajemen krisis public relations dalam menangani penolakan imunisasi measles rubella. 4(2), 290-311. 